ARTICLE

Received 4 Oct 2012 | Accepted 29 Mar 2013 | Published 30 Apr 2013 DOl: 10.1038/ncomms2829

\title{
Pyroclastic passage zones in glaciovolcanic sequences
}

\author{
James K. Russell ${ }^{1}$, Benjamin R. Edwards ${ }^{2}$ \& Lucy A. Porritt ${ }^{1,3}$
}

Volcanoes are increasingly recognized as agents and recorders of global climate variability, although deciphering the linkages between planetary climate and volcanism is still in its infancy. The growth and emergence of subaqueous volcanoes produce passage zones, which are stratigraphic surfaces marking major transitions in depositional environments. In glaciovolcanic settings, they record the elevations of syn-eruptive englacial lakes. Thus, they allow for forensic recovery of minimum ice thicknesses. Here we present the first description of a passage zone preserved entirely within pyroclastic deposits, marking the growth of a tephra cone above the englacial lake level. Our discovery requires extension of the passage-zone concept to accommodate explosive volcanism and guides future studies of hundreds of glaciovolcanic edifices on Earth and Mars. Our recognition of pyroclastic passage zones increases the potential for recovering transient paleolake levels, improving estimates of paleoice thicknesses and providing new constraints on paleoclimate models that consider the extents and timing of planetary glaciations.

\footnotetext{
${ }^{1}$ Volcanology and Petrology Laboratory, Earth, Ocean and Atmospheric Sciences, University of British Columbia, Vancouver, British Columbia, Canada V6T 1Z4. ${ }^{2}$ Department of Earth Sciences, Dickinson College, Carlisle, Pennsylvania 17013, USA. ${ }^{3}$ School of Earth Sciences, University of Bristol, Bristol BS8 1RJ, UK. Correspondence and requests for materials should be addressed to J.K.R. (email: krussell@eos.ubc.ca).
} 
G laciovolcanism encompasses all forms of interaction between volcanism and ice. The resulting volcanic deposits provide evidence for the timing and nature of glaciation and provide a record of paleoclimate and paleoenvironmental conditions and, thus, supply important constraints on planetary climate models. For example, glaciovolcanic edifices and their deposits are used forensically to recover properties of prehistoric ice sheets on Earth and Mars, including: thicknesses $^{1-5}$, hydrology ${ }^{4-7}$, timing ${ }^{1,6,8}$ and distributions ${ }^{9-11}$. Tools for interpreting the geological record of glaciovolcanism are, therefore, crucial to improving our abilities to test and refine rapidly evolving paleoclimate reconstruction models ${ }^{12,13}$.

Passage zones are diachronous surfaces marking transitions between subaqueous and subaerial depositional environments during volcanic eruptions; they form in a variety of littoral settings ${ }^{14-17}$. In glaciovolcanic settings, the elevation of the passage-zone surface unequivocally records the height and depth of the paleo-englacial lake at a specific point in time and space ${ }^{16-18}$. This elevation fixes the minimum thickness of the enclosing ice sheet and has been used as a paleoclimate proxy by constraining glaciations in both southern and northern hemispheres, including Antarctica ${ }^{5,8,16}$, Iceland ${ }^{7,19}$ and British Columbia ${ }^{1,20-23}$. However, previous workers have only identified glaciovolcanic passage zones ${ }^{16,17,22}$ within effusive volcanic sequences where the passage zone separates subaqueous lavafed delta lithofacies from overlying subaerial lavas.

We describe results from field mapping of a Pleistocene-aged subglacial volcano in northern British Columbia, Canada. Our mapping of a basaltic tephra cone at Kima'Kho Mountain has identified a unique passage zone that is hosted entirely within proximal volcaniclastic deposits resulting from explosive (versus effusive) eruption. Our discovery of a pyroclastic passage zone at Kima'Kho volcano demands reevaluation of the concept that most glaciovolcanic tephra cones were fully submerged and formed beneath the englacial lake surface $e^{9,11,17,18,21,22}$. Rather, subglacial tephra cones may record and preserve subaqueous to subaerial transitions in deposition (that is, passage zones), thereby, increasing the opportunities for forensic recovery of paleolake levels and estimates of paleo-ice thicknesses on Earth and Mars.

\section{Results}

Kima'Kho tuya. We have identified a new type of passage zone within an entirely explosive glaciovolcanic sequence from a subglacial volcano (that is, tuya) near Kawdy Mountain in northwestern British Columbia, Canada 22,24 . The Kima'Kho tuya is a highly dissected, small volume $\left(\sim 2-3 \mathrm{~km}^{3}\right)$, early Pleistocene $(1.82 \mathrm{Ma}+$ / $-40 \mathrm{ka}$ ) basaltic volcano ${ }^{24}$. The edifice forms a high relief structure covering $28 \mathrm{~km}^{2}$ and rising to an elevation of 1,946 m.a.s.l. on a regional, low-elevation plateau situated at $\sim 1,470$ m.a.s.l. (Fig. 1). The plateau hosts a total of six other tuyas ${ }^{20,22,24}$.

The major lithostratigraphic units and their relationships are summarized in a 4-km long cross-section drawn through Kima'Kho tuya (Fig. 1). The section comprises two S-N linear segments that bisect the middle of the edifice. The mapped geology is projected into the line of section; bedding attitudes are apparent and areas with poor exposure or talus cover are left blank (Fig. 1a). The volcano features a $476 \mathrm{~m}$ high, $\sim 3 \mathrm{~km}$ diameter, eroded tephra cone $\left(\sim 1.1-1.5 \mathrm{~km}^{3}\right)$ formed during an early explosive phase of eruption through an enclosing ice sheet (Fig. 1b). The cone comprises mostly vent-proximal $(<1 \mathrm{~km}$ from vent) volcaniclastic deposits; distal deposits are absent or not preserved. The tephra cone deposits were emplaced subaqueously below the level of the surrounding englacial lake, as well as subaerially once the cone built above lake level (Fig. 1). The transition between subaqueous and subaerial facies occurs at $\sim 1,850$ m.a.s.l. and defines a passage zone within pyroclastic deposits. Subsequent effusive eruptions formed an onlapping lava-fed delta ${ }^{25}$ comprising steeply dipping beds of pillow lava, pillow breccias and pillow-lava-derived hyaloclastite capped by subaerial lava sheets. This assemblage creates a minimum of two effusive passage zones situated at lower (1,630 and 1,695 m.a.s.l.) elevations (Fig. 1) and records the dynamic interplay between changes in the intensity of the effusive phase of eruption and changes in lake levels. Hence, Kima'Kho is a subglacial volcano that preserves passage-zone geometries in both explosive and effusive sequences ${ }^{20,22,24}$. The evidence for, and implications of, a passage zone within a pyroclastic succession are developed below.

Subaqueous pyroclastic deposits. The lower two-thirds of the exposed tephra cone comprises highly palagonitized, massive to crudely bedded (decimetre scale) lapilli tuffs (Fig. 2a,b). The deposits are moderately sorted, ranging from matrix to clastsupported, and locally show normal grading. The deposits comprise angular to subrounded, lapilli-sized and dense to vesicular basaltic pyroclasts within a palagonitized matrix of vitric ash particles. Grading and moderate sorting along with weak indicators of reworking (subrounded grains) suggest these deposits were subaqueously deposited. Relative to the volcaniclastic deposits situated above 1,850 m.a.s.l., these units: (1) have a higher proportion of subrounded juvenile clasts; (2) feature more layers that are clast-supported or show overall higher levels of sorting; and (3) never contain armoured lapilli (see below). These volcaniclastic deposits are interpreted to be products of subaqueous pyroclastic density currents continuously fed by subaqueous tephra jets, with little to minor reworking ${ }^{26,27}$.

Subaerial pyroclastic deposits. The subaqueous volcaniclastic deposits are overlain at $\sim 1850$ m.a.s.l. by a more diverse package of pyroclastic units. The majority of these pyroclastic deposits comprise massive to coarsely bedded (metre scale), outward dipping $\left(14^{\circ}-24^{\circ}\right)$, weakly palagonitized lapilli tuff. Locally, the lapilli tuff is well bedded (cm-scale), moderately sorted, and exhibits lenticular- and cross-bedding defined by horizons of coarser pyroclasts associated with minor finely bedded surge-like deposits (Fig. 2c). The majority of these deposits are matrix-supported, with a matrix of palagonitized, ash-sized blocky glass particles. The lapilli- to block-sized basaltic juvenile pyroclasts within the lapilli tuff are equant in shape, subrounded to angular, dense to vesicular $(\leq 40 \%)$ and aphanitic to glassy.

These deposits are distinct in that they contain armoured lapilli (Fig. 2d,e), a variety of accretionary lapilli featuring a single, central nucleus of a juvenile or lithic clast that is concentrically coated by fine-to-coarse ash (Fig. $2 \mathrm{f})^{28-32}$. The armoured lapilli are pervasive and distributed exclusively within the upper portion of the pyroclastic sequence along the highest ridge of the southern flank of the volcano (Fig. 1). They are commonly $0.3-2 \mathrm{~cm}$ in diameter, spherical to ovoid in shape, smooth surfaced (Fig. 2d-f) and occur in two modes: (a) dispersed ( $<2$ volume percent) on the decimetre scale within massive to crudely bedded pyroclastic deposits comprising matrix-supported palagonitized lapilli tuff or (b) concentrated ( $>50$ volume $\%$ ) within discrete, cm-scale, continuous-to-lensoidal beds within the lapilli tuff (Fig. 2d). The cores are scoriaceous fragments $(<2 \mathrm{~cm})$ of juvenile, vitric and olivine-phyric basalt, and the interface between the core and ash-aggregate rim is irregular, cuspate or jagged (Fig. 2f). The ash-aggregate envelopes are 1-5-mm thick, massive and comprise $10-150 \mu \mathrm{m}$ blocky-to-cuspate fragments of variably vesicular, angular to subangular ash particles (Fig. 2e,f). Less commonly, the armoured lapilli show weak concentric layers that fine outwardly. 


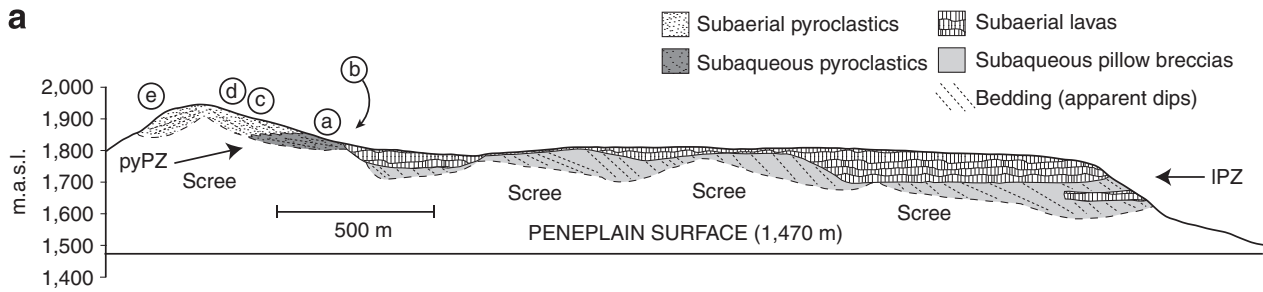

b

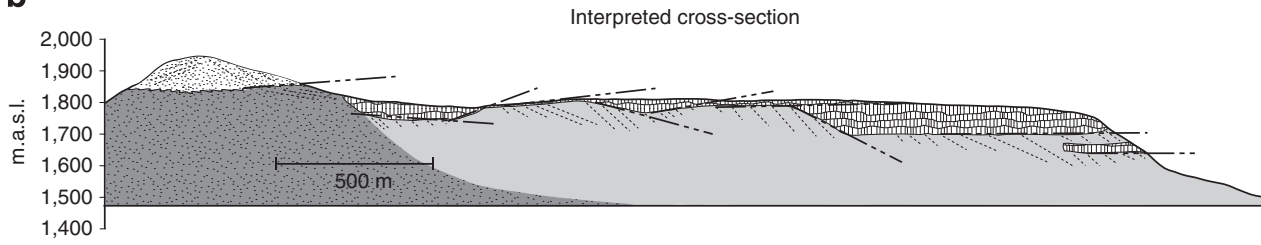

Figure 1 | Passage zones preserved in a Pleistocene tuya in north-central British Columbia. (a) Geological cross-section showing projected distribution of volcanic lithofacies used to define passage zones (pyPZ, pyroclastic passage zone; IPZ, classic lava delta passage zone). Letters on cross-section are keyed to field photographs displayed in Figure 2. (b) Cross-section showing the interpreted geology of Kima'Kho volcano; the volcanic lithofacies are used to define a pyroclastic passage zone, effusive passage zones and overlap structures (dashed lines) with rising, falling and horizontal passage zones all preserved at Kima'Kho.

The armoured lapilli show no evidence for disaggregation or reworking.

The stratigraphic succession is interpreted as comprising deposits resulting from the near-continuous production of ventproximal, wet, dilute pyroclastic density currents (that is, flow and surge) as the pyroclastic cone emerged from the englacial lake. The top of this pyroclastic sequence features discontinuous, remnant exposures of oxidized, well-sorted scoriaceous basaltic tephra interpreted to be air-fall deposits.

Discrimination of subaqueous and subaerial pyroclastic deposits. The discrimination of vent-proximal volcaniclastic deposits into subaqueous versus subaerial facies is a major challenge ${ }^{2,16,27}$. The lack of run-out distance provides little opportunity for the different media (water versus air) to modify pyroclast deposition sufficiently to create diagnostic differences. Vent-proximal pyroclastic deposits tend to be massive to weakly stratified and poorly to weakly sorted, regardless of depositional environment. Key features that can aid in discrimination are: the presence of bomb sags (subaerial), finely graded interlayers between depositional events (subaqueous), the relative degrees of sorting within the entire succession (better sorting and subaqueous) and lateral facies changes away from the vent (more rapid increase in sorting and subaqueous).

At Kima'Kho, the abrupt and pervasive appearance of armoured lapilli, in conjunction with the simultaneous subtle change in the character of volcaniclastic deposits, is taken as diagnostic of a subaerial environment and, thus, indicative of an emergent tephra cone ${ }^{33}$. Ash aggregation occurs via the collision of moist ash particles suspended in turbulent dilute plumes due to convective upwelling and differences in particle settling velocities $^{34,35}$. The formation of armoured lapilli requires highintensity explosive eruptions to produce abundant fine ash particles, a dilute, ash-rich, convecting plume to allow for frequent particle collisions and moisture on particle surfaces to bind the fine ash particles. The fine ash rims on the armoured lapilli are, thus, indicative of circulation within a dilute, sustained ash-rich eruption plume (or flow), and their formation is strong evidence for a subaerial environment ${ }^{36}$ above the surface of the englacial lake.

Ash aggregates are unlikely to survive deposition in subaqueous deposits. Indeed, few published accounts of ash aggregates within subaqueous volcaniclastic deposits exist ${ }^{27,37}$, and their origins in these deposits are as complex as they are rare or involve deposition in shallow water. Armoured lapilli formed in and sedimented from eruption columns in vent-proximal environments are unlikely to survive deposition or transport in deep (see below) water. Feasible cementation processes, including precipitation of salts and freezing, are much more likely to affect aggregates with prolonged within-plume residence times, which would be more pertinent to medial and distal tephra deposits. The armoured lapilli at Kima'Kho are pervasively distributed in deposits that are proximal $(<0.5 \mathrm{~km})$ to the inferred vent. They are only present above a specific stratigraphic level and elevation, and show no evidence for post-deposition transport, disaggregation or reworking. On this basis, they provide strong evidence of subaerial formation and deposition.

\section{Discussion}

The volcanic stratigraphy at Kima'Kho records the growth and emergence of a tephra cone preserving a pyroclastic passage zone. Based on the elevation of the basement underlying Kima'Kho (1,470 m.a.s.l.), the high stand of the englacial lake was $\sim 380 \mathrm{~m}$ in depth. The depth of that ice-impounded lake implies a minimum local thickness for the surrounding ice sheet of $>425 \mathrm{~m}$ to balance the hydrostatic pressure and prevent drainage events associated with lifting of the ice ${ }^{1,5,16,38,39}$. We do not know if Kima'Kho was in the middle or near the edge of the ice sheet at the time of eruption, however, this minimum estimate of ice thickness implies a surrounding ice sheet of radius of $\sim 15-22 \mathrm{~km}$ (ref. 40). The Kawdy Plateau is situated $\sim 200-300 \mathrm{~m}$ above the surrounding valleys, which would allow for a total ice thickness $600-800 \mathrm{~m}$ and imply $\sim 35-60 \mathrm{~km}$ of surrounding ice. Regardless of these uncertainties, this constitutes important first evidence for a major ice accumulation in the Canadian cordillera ca. $1.8 \mathrm{Ma}$.

The upper surfaces of ice sheets commonly comprise firn, which is moderately permeable $\left(10^{-4}-10^{-5} \mathrm{~cm}^{2}\right)^{41}$ relative to dense glacier ice. Although the transport capability of melt water within this layer is very low ${ }^{40}$, it allows the possibility of stored englacial lake waters draining through the upper portion of the glacier ${ }^{16,42,43}$. Depths to the firn-ice transition vary somewhat (15-115 m (ref. 40)) depending on the type of glacier (polar versus temperate). For a large glacier or ice cap covering the 


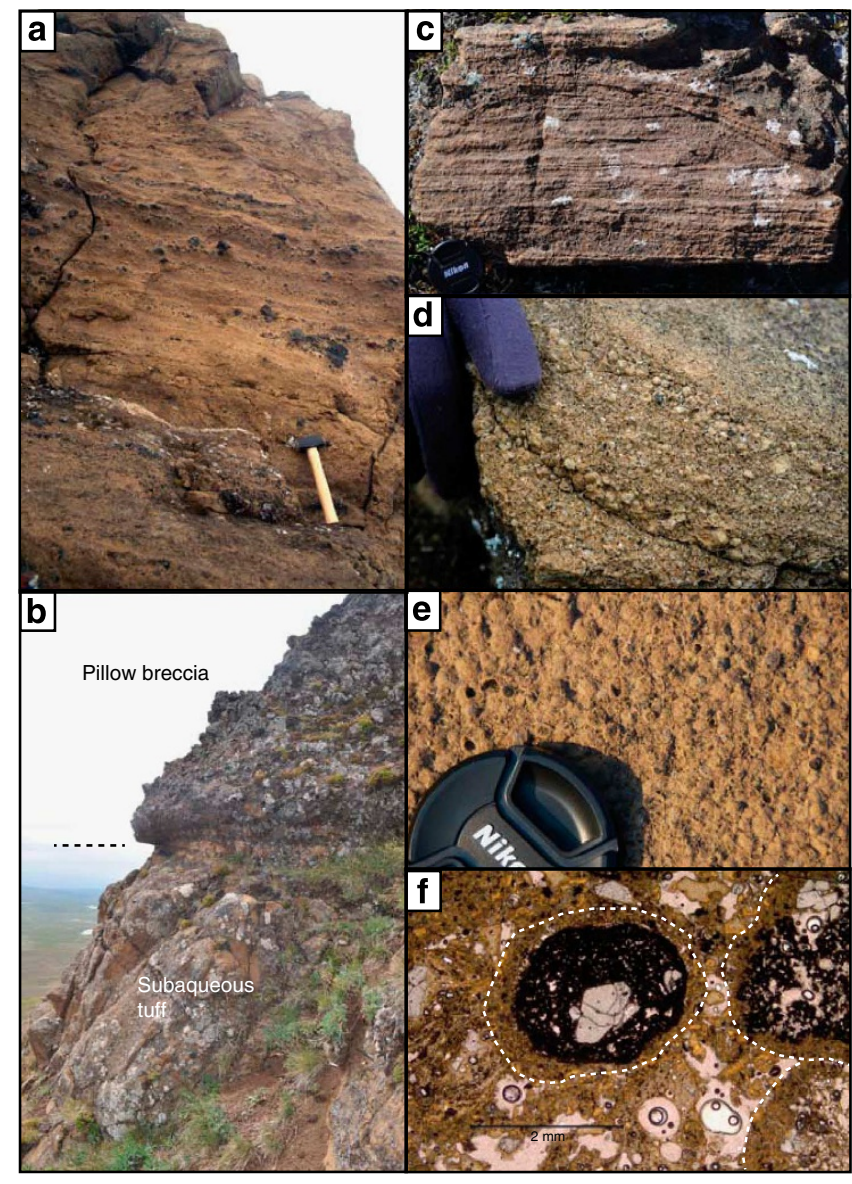

Figure 2 | Photographs of outcrops and photomicrographs of armoured lapilli. Images are connected to locations in cross-section (Fig. 1) by letters. (a) Massive to diffusely bedded, poorly sorted, subaqueous proximal mass flows or pyroclastic density currents. (b) Contact between subaqueously deposited lapilli tuff and overlying pillow breccia and hyaloclastite. (c) Mm$\mathrm{cm}$-scale planar laminated, moderately sorted, subaerial pyroclastic surge beds. (d) Discontinuous lenses and layers of $\mathrm{cm}$-sized armoured lapilli within proximal, subaerial fall-modified pyroclastic density current deposits (surge and flow). (e) Close-up image of armoured lapilli on bedding surface. (f) Photomicrograph of armoured lapilli showing vesicular glassy pyroclast coated in fine ash.

Kawdy Plateau, we would expect a transition depth of $\sim 70 \mathrm{~m}$. If the paleolake level defined by the pyroclastic passage zone was controlled solely by the transition from impermeable ice to more permeable firn, the reconstructed ice sheet would have to be $\sim 450 \mathrm{~m}$ thick $(380+70 \mathrm{~m})$. An alternate, and more efficient, form of drainage involves supraglacial stream channels that cut through the ice surface to ultimately connect with the subsurface subglacial drainage systems ${ }^{43}$. Supraglacial drainage would result where the englacial lake fills at a rate that cannot be alleviated by drainage through the firn.

Recognition of the pyroclastic passage zone at Kima'Kho is significant because it records the earliest and highest lake level during the eruption and, hence, provides the best estimate of minimum ice sheet thickness. Lower lake level stands are recorded by the later effusive passage-zone sequences (Fig. 1). The preservation of a subaqueous to subaerial transition within the pyroclastic sequence at Kima'Kho demonstrates that many other glaciovolcanic tephra cones, mounds or ridges ${ }^{4,5,21,44}$ may also host mappable passage zones that can also be interrogated for quantitative estimates of paleolake elevations and minimum ice thicknesses.
Subaqueous to subaerial transitions based on the 'classic' effusive glaciovolcanic eruption sequences have been classified by Smellie $^{16}$ into five categories. Within this context, he recognized two types of transition: overlap structures and passage zones (sensu stricto). Overlap structures (Fig. 3) need not be cogenetic and represent diastems, involving subaerial lava overlying or abutting against earlier volcaniclastic subaqueous lithofacies ${ }^{15,16}$. Passage zones (sensu stricto ${ }^{17}$ ) separate two coeval and cogenetic lithofacies (subaqueous and subaerial) that mark, in space and time, the exact height of the englacial lake. Passage zones are classified geometrically as: horizontal, rising or falling (Fig. 3). Our work requires an extension of this classification to include passage zones comprising coeval explosive subaqueous to subaerial transitions within pyroclastic successions (Fig. 3).

The geometry of effusive and explosive passage zones can be subtly different because their surfaces propagate differently in response to rising englacial lake levels. For effusive passage zones, the subaqueous delta must expand laterally before the lava can override $i^{25}$. If the englacial lake level is rising more rapidly than the edifice is growing, effusive passage zones migrate upwards and towards the vent due to the transgressive nature of the deltaic assemblage (Fig. 3). Pyroclastic passage zones record the lateral facies changes from a subaerial (pyroclastic flow, surge and fall deposits) to a subaqueous (turbidity currents, water-lain fall) depositional environment. This interface continually migrates laterally away from the vent as the cone builds upwards and outwards with each successive deposit. Thus, a pyroclastic passage zone will tend to migrate away from the vent as the tephra cone grows simultaneously (Figs 3 and 4 ).

All passage zones are diachronous and, thus, document dynamic changes in englacial lake levels through time ${ }^{16}$. Slopes of passage zones record the rates of rise in englacial lake levels relative to the rates of edifice growth (Fig. 4). Most glaciovolcanic tephra cones originate in a subaqueous environment ${ }^{16}$ and then grow upwards and outwards until a time $\left(T_{0}\right)$ when the cone becomes emergent and the first passage-zone forms (Fig. 4). Growth of the tephra cone within a stable englacial lake (Figs 3 and $4 \mathrm{a}$ ), where the water added by melting or displaced by edifice growth is balanced by drainage, results in a horizontal passage zone. This steady-state situation can identify the height of the supraglacial drainage system or can be used to estimate background drainage rates $3,5,16$. In contrast, rising (Fig. 4b) or falling lake levels (Fig. 4c) during tephra cone growth result in concave-up or concave-down parabolic passage-zone surfaces, respectively. Passage zones are continuous in time and, unless the edifice geometry changes dramatically (that is, sector collapse) or the lake level drops, they form continuous surfaces. For example, if the lake rises to a level that causes hydrostatic lifting of the ice sheet, a deluge will occur (that is, jökulhlaup) draining or partially draining the englacial lake $\mathrm{e}^{16,39}$. This causes a discontinuity and drop in the passage zone (Fig. $4 \mathrm{~d}$ ); the elevation drop is indicative of the magnitude of the deluge event.

The Kima'Kho stratigraphic succession documents a transition from an early explosive eruptive phase expressed as a $480-\mathrm{m}$ high, $1.1-1.5 \mathrm{~km}^{3}$ tephra cone to an effusive eruption that produced subaqueously deposited beds of pillow breccias and hyaloclastite capped by subaerial lavas. At Kima'Kho, melting of the overlying and surrounding ice during the early explosive phase of eruption resulted in an englacial lake. Initially, lake level rose rapidly enough to outpace the concomitant growth of the subaqueous tephra cone (Fig. 1a, pyPZ), as is commonly observed in other tephra cone-building subglacial eruptions ${ }^{5,45}$. Explosive glaciovolcanic eruptions or effusive eruptions associated with high-efficiency quench fragmentation commonly produce the highest rates of ice melting ${ }^{44}$. They maximize damage to the overlying ice and produce the most significant hazards from melt 


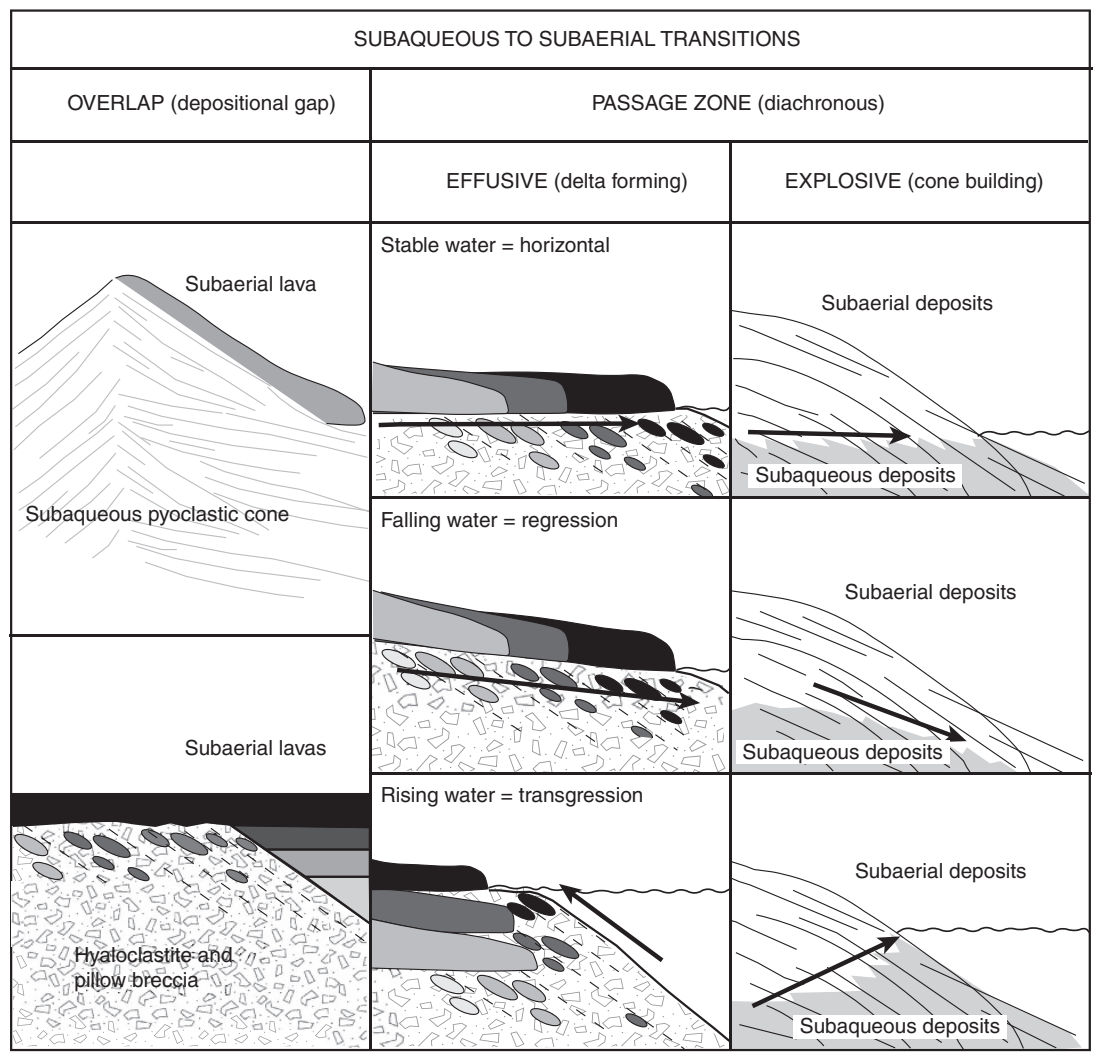

Figure 3 | Classification of subaqueous to subaerial transitions in effusive and explosive glaciovolcanic sequences. Classification scheme

comprises: overlap structures (left panels) and passage zones (right panels). Overlap structures represent diastems involving subaerial lava juxtaposed with earlier subaqueous volcaniclastic lithofacies; the two facies are not cogenetic and coeval. Passage-zone surfaces separate cogenetic lithofacies that are indicative of subaqueous and subaerial deposition. Effusive passage zones feature coherent lavas overrunning coeval and genetically related volcaniclastic deposits (for example, pillow lava, breccias and hyaloclastite). Passage zones derived from explosive glaciovolcanism comprise subaerial pyroclastic deposits (that is, fallout, surge and flow) transitioning along strike into subaqueously deposited equivalents.

water floods ${ }^{12,44}$. The rapid rise of the lake and the early subaqueous origin of the cone are easily explained by the fact that explosive subglacial eruptions are $70-80 \%$ efficient with respect to the transfer of heat from the magma to the surrounding ice ${ }^{44}$. Most importantly, this efficiency is independent of the magnitude of eruptive flux, and heat transfer operates on the timescale of the eruption (that is, not post emplacement).

These heat-transfer constraints indicate that the minimum estimated volume of tephra $\left(1.1 \mathrm{~km}^{3}\right)$ at Kima'Kho could have melted $\sim 3.1 \mathrm{~km}^{3}$ of ice. This would translate into the potential melting of a 3-km diameter cylindrical hole (for example, base of Kima'Kho) through $\sim 435 \mathrm{~m}$ of overlying ice. The heat balances accord well with the elevation of the pyroclastic passage zone at Kima'Kho, which implies a 380-m deep stable englacial lake requiring a minimum ice thickness of $\sim 425 \mathrm{~m}$. For a 425 -m thick ice sheet, the explosive phase of eruption would need to melt $\sim 3 \mathrm{~km}^{3}$ of ice to create a cylindrical hole in the ice to accommodate the $3-\mathrm{km}$ diameter tephra cone. This would create $2.7 \mathrm{~km}^{3}$ of melt water that would fill the hole to a level of $382 \mathrm{~m}$. The maximum amount of melt water within the cauldron defined by the height of the englacial lake and accounting for the volume displaced by the $1.1 \mathrm{~km}^{3}$ of tephra (that is, pyroclastic cone) is $1.6 \mathrm{~km}^{3}$. Thus, the total melt water generated $\left(2.7 \mathrm{~km}^{3}\right)$ and the peak lake level elevation demand a syn-eruptive drainage of $\sim 1.1 \mathrm{~km}^{3}$ to maintain the lake surface elevation recorded by the pyroclastic passage zone.

Effusive eruptions forming pillow piles are less efficient $(10-45 \%)$ at transferring heat on a timescale that keeps pace with normal eruption rates ${ }^{38,44,46}$. The lower limits $(10 \%)$, for example, might describe the heat-transfer efficiency of pillow piles that are growing endogenously. The underlying pillow pile will continue to release heat as the eruption progresses and may even release more enthalpy per mass unit than their more glassy pyroclastic equivalents (that is, latent heat of crystallization). However, the main effect of this delayed heat transfer is to heat melt water rather than to directly melt the ice. At Kima'Kho, an equal volume of lava would only have melted $\sim 0.4-2.0 \mathrm{~km}^{3}$ of ice and have been limited to melting $\sim 62-280 \mathrm{~m}$ of overlying ice. Thus, the early explosive phase allows for more rapid melting of ice and heating of the englacial lake. In many situations, the tephra cone may never become emergent but, at Kima'Kho, cone build-up caught and surpassed the lake level rise, at which point a pyroclastic passage zone was formed.

The Kima'Kho tuya records repeated events where the growth of the volcanic edifice was able to surpass rates of lake level rise to create several passage zones (Fig. 1). The spatial organization of the early pyroclastic passage zone (Fig. 1a, pyPZ) and later effusive passage zones (Fig. 1a, lPZ) illustrates the highly dynamic and transient character of the englacial lake and can be used to constrain the rates of lake level rise and fall relative to competing rates of magma discharge (Fig. 4). The effusive passage zones at Kima'Kho occur at lower elevations, comprise subaqueous deposits of pillow breccia and hyaloclastite overlain by subaerial lavas, and are similar to lava-fed deltas described by previous workers in Canada ${ }^{1,22}$, Iceland ${ }^{47}$ and Antarctica ${ }^{16}$. These passage zones formed during the late-stage effusive phase of eruption and are situated between 1,800 and 1,630 m.a.s.l. (Fig. 1b), indicating that, at some point, the englacial lake drained and lake level 


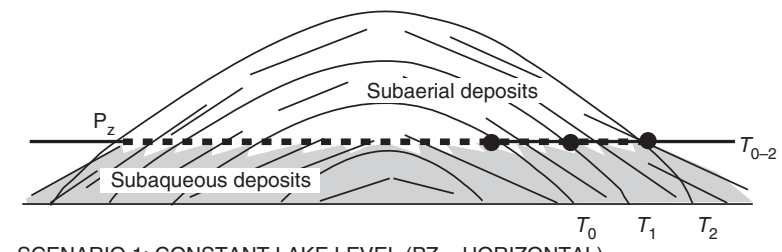

SCENARIO 1: CONSTANT LAKE LEVEL (PZ = HORIZONTAL)

b

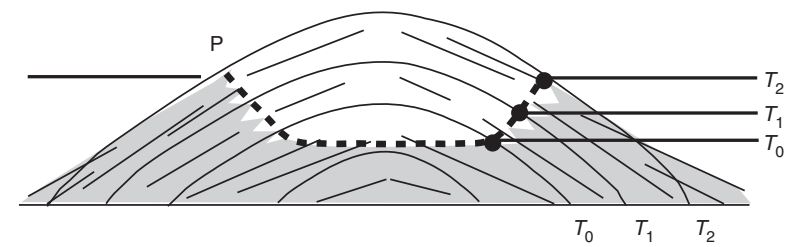

SCENARIO 2: RISING LAKE LEVEL (PZ = CONCAVE UPWARDS)

C

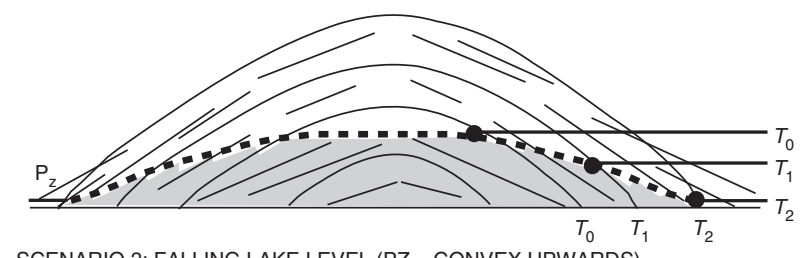

SCENARIO 3: FALLING LAKE LEVEL (PZ = CONVEX UPWARDS)

d

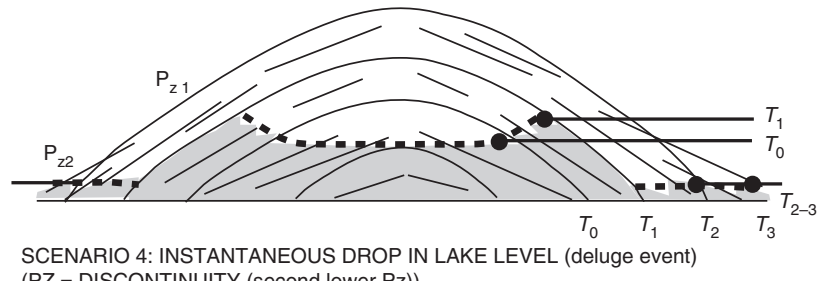

(PZ = DISCONTINUITY (second lower PZ))
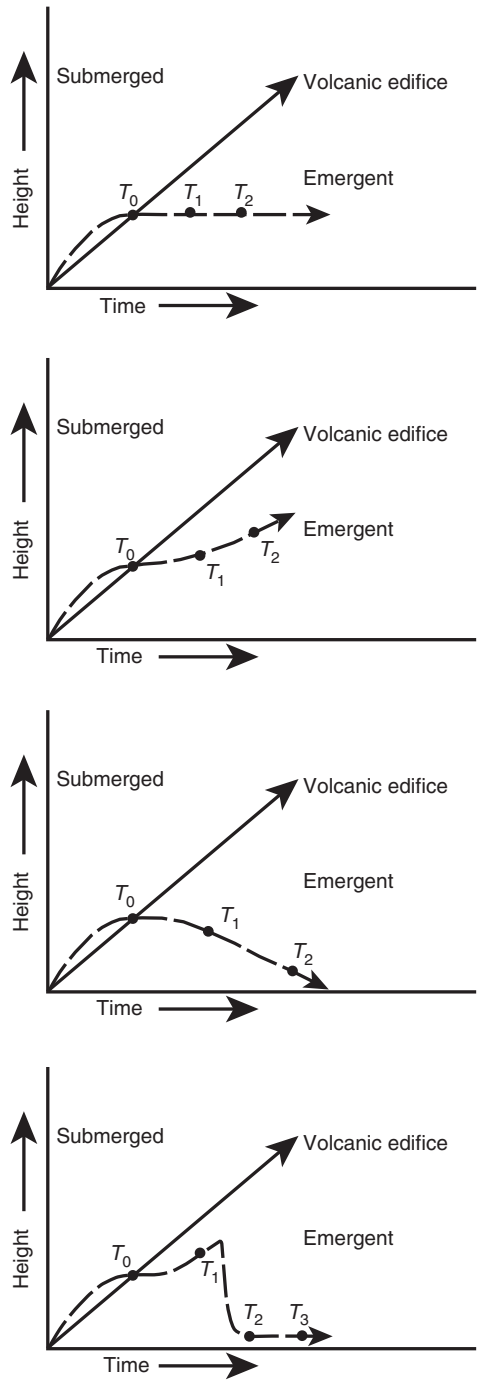

Figure 4 | Geometric and temporal evolution of passage zones in glaciovolcanic pyroclastic successions. The panels on the left show the growth of the volcanic edifice and the resulting displacement of the passage zone (PZ) for different times $\left(T_{0}, T_{1}, T_{2}\right)$ depending on the behaviour of the englacial lake. Panels on the right portray the corresponding height-time evolution of the PZ as a function of rates of volcano growth (solid arrows) versus rise of englacial lake (dashed arrows). Lake level rises ahead of the tephra cone until $T_{0}$ where cone becomes emergent creating the first points on the PZ surface. Generalized scenarios include: (a) tephra cone emerges and lake level remains constant while volcano continues to grow, resulting in a horizontal PZ; (b) cone and lake rise simultaneously resulting in a concave-up parabolic PZ surface; the gradient (that is, slope) of the PZ surface defines the relative rates of edifice to lake rise; (c) edifice grows while lake level decreases producing a concave-down parabolic PZ surface; the gradient (negative) of the surface defines the relative rates of edifice to lake rise and fall; (d) Edifice and lake level rise creating a concave-upwards PZ surface. The lake level rises to cause hydrostatic lifting of the ice sheet and a deluge occurs, draining or partially draining the intraglacial lake. This causes a discontinuity and drop in the passage-zone surface.

dropped $\sim 220 \mathrm{~m}$ relative to its original high stand. This drop in paleolake level is probably indicative of a large $\left(\sim 1.1-1.4 \mathrm{~km}^{3}\right)$ jökulhlaup. The higher-elevation effusive passage zone varies in elevation on the order of a few tens of metres (Fig. 1b), which is typical of englacial lakes having non-steady lake levels ${ }^{16}$.

In areas on Earth and Mars where volcanism and glaciation have been contemporaneous, volcanoes have established the timing and minimum thicknesses of former ice sheets $s^{2,79-11,16,48}$. In many cases, glaciovolcanic deposits are the only tool available for reconstructing the thickness of paleo-ice sheets and recovering paleoclimatological information. Although the identification of key facies in pyroclastic sequences indicative of passage zones is a formidable challenge ${ }^{16}$, their recognition and their utility is a significant development for terrestrial and planetary geosciences. The distinctive flat-topped tuyas have long been used to recover syn-eruption, englacial lake levels 1,3,19,22. However, these 'classic' tuyas are commonly subordinate to other types of glaciovolcanoes (that is, ridges and tephra mounds) on Earth and Mars $5,10,21,39$. Past practices have largely ignored subglacial tephra mounds and ridges for recovering detailed paleoclimate information because they are assumed to be fully submergent ${ }^{5,18,21}$. For example, Ghatan and Head ${ }^{11}$ identified 17 prospective glaciovolcanic features in the south polar region of Mars; of these, 9 have conical shapes and 8 are flat-topped. The flat-topped (that is, lavacapped) tuyas are expected to preserve passage zones, and, following common practice, Ghatan and Head ${ }^{11}$ used tuya heights to estimate ice thicknesses of $700-1,300 \mathrm{~m}$ for this region of Mars. However, for the conical subglacial volcanoes, the enclosing ice sheets were estimated to be twice as thick ${ }^{11}$ because convention suggests that the conical subglacial never became 
emergent. Our recognition and exploration of the pyroclastic passage zone preserved in the tephra cone at Kima'Kho provides one possible way to reconcile these disparate estimates of ice thicknesses. It is possible that the conical edifices on Mars host unmapped passage zones; this would reduce the peak heights of the paleo-englacial lakes and the minimum estimates of ice thickness.

Re-examination of these and hundreds of other Martian and terrestrial glaciovolcanoes is now warranted, given the potential for finding unrecognized passage zones resulting from the 'explosive' glaciovolcanic eruptions. Exploitation of this untapped database will provide new and potentially better estimates of paleo-ice sheet thicknesses and distributions that will be critical for testing increasingly sophisticated paleoclimate reconstructions for Earth and Mars.

\section{Methods}

Field mapping and sampling. This research is based on a field mapping and sampling campaign at Kima'Kho Mountain, northwestern British Columbia, completed in the summer of 2010. The 5-week field campaign was helicoptersupported, and the overarching goal was to map and understand the stratigraphic relationships preserved in this well-dissected volcanic edifice. The mapping was accomplished via traverses that crossed the major geological contacts and mapping of vertical sections at localities hosting key contacts. The field-mapping exercise resulted in a 1:20,000 scale geological map for the volcano ${ }^{24}$, a series of detailed (1:200 scale) graphic logs, field photographs of contact relationships and each mappable unit (Fig. 2), and collection of samples for subsequent laboratory analysis.

Microscopy. Select rock samples from critical map units were slabbed and prepared as polished thin sections for study by transmitted-light and scanning electron microscopy. Detailed examination of slabs and thin sections was used to identify the mineralogy and textures of the coherent volcanic rocks (for example, lavas and dykes) and the componentry, grain-size distributions, and the textural properties of pyroclasts (subaqueously and subaerially deposited volcaniclastic units). Additional polished thin sections and scanning electron microscopy mounts were prepared and analysed in support of our detailed microscopic study of the armoured lapilli (Fig. 2).

\section{References}

1. Edwards, B. R., Russell, J. K. \& Simpson, K. Physical and chemical evolution of Mathews Tuya, northern British Columbia, Canada: evidence for a pre-LGM Cordilleran icesheet. Bull. Volcanol. 73, 479-496 (2010).

2. Jakobsson, S. P. \& Gudmundsson, M. T. Subglacial and intraglacial volcanic formations in Iceland. Jokull 58, 179-196 (2008).

3. Smellie, J. L. Basaltic subglacial sheet-like sequences: Evidence for two types with different implications for the inferred thickness of associated ice. Earth Sci. Rev. 88, 60-88 (2008).

4. Smellie, J. L. \& Skilling, I. Products of subglacial volcanic eruptions under different ice thicknesses: two examples from Antarctica. Sedimentary Geol. 91, 115-129 (1994).

5. Smellie, J. L in Encyclopedia of Quaternary Science (Elias, S. A. eds.) 784-798 (Elsevier, 2007).

6. McGarvie, D. W. Rhyolitic volcano-ice interactions in Iceland. J. Volcanol. Geothermal Res. 185, 367-389 (2009).

7. Werner, R. \& Schmincke, H. Englacial vs lacustrine origin of volcanic table mountains: evidence from Iceland. Bull. Volcanol. 60, 336-354 (1999).

8. Smellie, J. L., Rocchi, S., Gemellie, M., di Vincenzo, G. \& Armienti, P. Late Miocene East Antartic ice sheet characteristics deduced from terrestrial glaciovolcanic sequences in northern Victoria Land, Antartica. Palaeogeography Palaeoclimatol. Palaeoecol. 307, 129-149 (2011).

9. Allen, C. C. Volcano-ice interactions on Mars. J. Geophys. Res. 84, 8048-8059 (1979).

10. Chapman, M. G. et al.in Deep Oceans to Deep Space: Environmental Effects on Volcanic Eruptions (Gregg, T. K. P. \& Zimbelman, J. R. eds.) 39-74 (Plenium Press, New York, 2000).

11. Ghatan, G. J. \& Head, I. I. I. J. W. Candidate subglacial volcanoes in the south polar region of Mars: morphometry and eruption conditions. J. Geophys. Res. 107, 2-1-2-19 (2002).

12. Tuffen, H. \& Betts, R. Volcanism and climate: chicken and egg (or vice versa)? Philos. Trans. R. Soc. Lond. B Biol. Sci., Series A 368, 2585-2588 (2010).

13. Edwards, B. R., Tuffen, H., Skilling, I. \& Wilson, L. Introduction to special issue on volcano-ice interactions on Earth and Mars: the state of the science. J. Volcanol. Geothermal Res. 185, 247-250 (2009).
14. Jones, J. G. \& Nelson, P. H. H. The flow of basalt lava from air into water-its structural expression and stratigraphic significance. Geol. Mag. 107, 13-19 (1970).

15. Nelson, P. H. H. The James Ross Island Volcanic Group of north-east Graham Land. Br. Antartic Surv. Sci. Rep. 54, 1-64 (1975).

16. Smellie, J. L. The relative importance of supraglacial versus subglacial meltwater escape in basaltic subglacial tuya eruptions: an important unresolved conundrum. Earth Sci. Rev. 74, 241-268 (2006).

17. Jones, J. G. Intraglacial volcanoes of the Laugarvatn region, south-west IcelandI. Geol Soc. Lond. Quarterly J. 124, 197-211 (1969).

18. Allen, C. C., Jercinovic, M. J. \& Allen, J. S. B. Subglacial volcanism in NorthCentral British Columbia and Iceland. J. Geol. 90, 699-715 (1982).

19. McGarvie, D. W., Stevenson, J. A., Burgess, R., Tuffen, H. \& Tindle, A. G. Volcano-ice interactions at Prestahnúkur, Iceland: rhyolite eruption during the last interglacial-glacial transition. Ann. Glaciol. 45, 38-47 (2007).

20. Edwards, B. R. \& Russell, J. K. The distribution, nature and origin of NeogeneQuaternary magmatism in the Northern Cordilleran Volcanic Province, northern Canadian Cordillera. Geol. Soc. Am. Bull. 112, 1280-1295 (2000).

21. Hickson, C. J. Physical controls and resulting morphological forms of Quaternary ice-contact volcanoes in western Canada. Geomorphology 32, 239-261 (2000).

22. Mathews, W. H. "Tuyas," flat-topped volcanoes in Northern British Columbia. Am. J. Sci. 245, 560-570 (1947).

23. Edwards, B. R. et al. Evolution of an englacial volcanic ridge: Pillow Ridge tindar, Mount Edziza volcanic complex, NCVP, British Columbia, Canada. J. Volcanol. Geothermal Res. 185, 251-275 (2009).

24. Ryane, C., Edwards, B. R. \& Russell, J. K. The volcanic stratigraphy of Kima'Kho Mountain: a Pleistocene tuya, northwestern British Columbia. Geol. Surv. Can. Curr. Res. 2011-14, 1-16, doi:10.4095/289196 (2011).

25. Skilling, I. P in Volcano-Ice Interaction on Earth and Mars (Smellie, J. L. \& Chapman, M. G. eds.) 195-211 (Geological Society of London Special Publication 202, 2002).

26. Kokelaar, B. P. The mechanism of Surtseyan volcanism. J. Geol. Soc. Lond. 140, 939-944 (1983).

27. White, J. D. L. Pre-emergent construction of a lacustrine basaltic volcano, Pahvant Butte, Utah (USA). Bull. Volcanol. 58, 249-262 (1996).

28. Brown, R. J., Branney, M. J., Maher, C. \& Dávila-Harris, P. Origin of accretionary lapilli within ground-hugging density currents: Evidence from pyroclastic couplets on Tenerife. Geol. Soc. Am. Bull. 122, 305-320 (2010).

29. Lorenz, V. Vesiculated tuffs and associated features. Sedimentology 21, 273-291 (1974).

30. Schumacher, R. \& Schmincke, H. U. Internal structure and occurrence of accretionary lapilli; a case study at Laacher See Volcano. Bull. Volcanol. 53, 612-634 (1991).

31. Waters, A. C. \& Fisher, R. V. Base surges and their deposits: Capelinhos and Taal volcanoes. J. Geophys. Res. 76, 5596-5614 (1971).

32. Wohletz, K. H. \& Sheridan, M. F. Hydrovolcanic explosions II. Evolution of basaltic tuff rings and tuff cones. Am. J. Sci. 283, 385-413 (1983).

33. Schopka, H. H., Gudmundsson, M. T. \& Tuffen, H. The formation of Helgafell, southwest Iceland, a monogenetic subglacial hyaloclastite ridge: Sedimentology, hydrology and volcano-ice interaction. J. Volcanol. Geothermal Res. 152, 359-377 (2006).

34. Sparks, R. S. J. et al. Volcanic Plumes 597 (Wiley, 1997).

35. Gilbert, J. S. \& Lane, S. J. The origin of accretionary lapilli. Bull. Volcanol. 56, 398-411 (1994).

36. Brown, R. J., Bonadonna, C. \& Durant, A. J. A review of volcanic ash aggregation. Phys. Chem. Earth 45-46, 65-78 (2012).

37. Fiske, R. S. Subaqueous pyroclastic flows in the Ohanapecosh Formation, Washington. Geol. Soc. Am. Bull. 74, 391-406 (1963).

38. Kelman, M. C., Russell, J. K. \& Hickson, C. J. Effusive intermediate glaciovolcanism in the Garibaldi Volcanic Belt, southwestern British Columbia, Canada. Geol. Soc. Lond. Spec. Publ. 202, 195-211 (2002).

39. Smellie, J. L. in Encyclopedia of Volcanoes (Sigurdsson, H. et al. eds.) 403-418 (Academic Press, 2000).

40. Paterson, W. S. Physics of Glaciers (Pergamon Press, 1994).

41. Albert, M. A., Shultz, E. F. \& Perron, F. E. Snow and firn permeability at Siple Dome, Antartica. Ann. Glaciol. 31, 353-356 (2000).

42. Magnússon, E. et al. Ice-volcano interactions during the 2010 Eyjafjallajökull eruption, as revealed by airborne imaging radar. J. Geophys. Res. 117, B07405 (2012).

43. Jarosch, A. H. \& Gudmundsson, M. T. A numerical model for meltwater channel evolution in glaciers. The Cryosphere 6, 493-503 (2012).

44. Gudmundsson, M. T in Subaqueous explosive volcanism Vol. 140 (White, J.D.L., Smellie, J. L. \& Clague, D. A. eds.) 61-72 (Geophysical Monograph, 2003).

45. Smellie, J. L in Preservation of Random Mega-scale Events on Mars and Earth: Influence on Geologic History Vol. 453 (Chapman, M. G. \& Leszthely, L. eds.) 55-76 (Geological Society of America Special Papers, 2009). 
46. Allen, C. C. Icelandic subglacial volcanism: thermal and physical studies. J. Geol. 88, 108-117 (1980).

47. Skilling, I. P. Subglacial to emergent basaltic volcanism at Hlöðufell, south-west Iceland: a history of ice-confinement. J. Volcanol. Geothermal Res. 186, 276-289 (2009).

48. Tuffen, H., Owen, J. \& Denton, J. Magma degassing during subglacial eruptions and its use to reconstruct palaeo-ice thicknesses. Earth Sci. Rev. 99, $1-18(2010)$.

\section{Acknowledgements}

Funding for this research is from the National Science Foundation (NSF-ARRA 0910712 to B.R.E.), the Natural Sciences and Engineering Research Council (J.K.R.) and a Marie Curie outbound fellowship (L.A.P.). We thank Chanone Ryane for her assistance in the field and additional support from Stephan Kolzenburg.

\section{Author contributions}

B.R.E. and J.K.R. conceptualized the original idea, based on several years of working in the Tuya-Kawdy region, and made the field observations. L.A.P. provided volcanological expertise and context and conceptualized and drafted the figures. All co-authors contributed to producing a final draft manuscript for review and participated in revision.

\section{Additional information}

Competing financial interests: The authors declare no competing financial interests.

Reprints and permission information is available online at http://npg.nature.com/ reprintsandpermissions/

How to cite this article: Russell, J. K. et al. Pyroclastic passage zones in glaciovolcanic sequences. Nat. Commun. 4:1788 doi: 10.1038/ncomms2829 (2013). 